\title{
A Study on Teacher Candidates' Self-Efficacy, Motivation and Affection Levels for Children
}

\author{
Vesile Yildiz Demirtaş \\ Correspondence: Vesile Yildiz Demirtaş, Buca Faculty of Education, Dokuz Eytul Universtiy, İzmir, Turkey.
}

Received: September 29, 2018

Accepted: October 11, $2018 \quad$ Online Published: October 17, 2018

doi:10.11114/jets.v6i12.3661

URL: https://doi.org/10.11114/jets.v6i12.3661

\begin{abstract}
The purpose of this research is to reveal the levels of affection for children, teaching motivations and self-efficacy beliefs of the teacher candidates studying in special education, pre-school and primary school teaching departments based on their gender, classroom and academic branches to showcase the correlations between the levels of the teachers' affection for children, their self-efficacy beliefs and teaching motivations. The study group was determined with the criterion sampling method. 368 teacher candidates participated in this study: 108 from special education department, 136 from pre-school department and 136 from primary school teacher department. The data were collected by means of 'Barnett Liking Children, Teaching Motivations and Perception of Teacher Self-efficacy Scales'. The data were analyzed using independent group t-tests, one -way analysis of variance, Pearson's correlation analysis and simple linear regression analysis. The results show that the teacher candidates from the three departments have a high level of affection for children. Their motivations to teach and self-efficacy beliefs are higher than the average value. It is revealed that there is an average positive correlation between liking children and teacher self-efficacy in using teaching strategies. However, the data results disclosed that the teacher candidates' self-efficacy beliefs, students' participation, teaching motivations, and teaching strategies predict their affection for children significantly and positively. Teacher candidates should be enabled to establish direct experiences with the group they shall work with in order to develop the self-efficiency beliefs of them.
\end{abstract}

Keywords: liking children, teaching motivation, self-efficacy, teacher candidates (special education, pre-school and primary school departments)

\section{Introduction}

Nowadays, teaching has become a very important profession. The development of the society is closely linked to the efficacies and personal characteristics of teachers. Most researchers emphasize that teachers relatively should have more distinguished and distinctive characteristics than other workers in the society (Downing, Ryndak \& Clark 2000; Gelbal \& Duyan, 2010; Açıkgöz 2012; Kabaklı Çimen 2015). They should be innovative, have positive attitude towards students and teaching, be interested in music, painting, literature, be good readers, consider self-development, be sensitive, empathic, cooperative, flexible, compassionate, fair, have strong sense of responsibility, be experts, open to new things, contemplative, respectful and be patient. In addition to all these features, it is very important to carry out this profession willingly and voluntarily in order to be successful at work which requires patience, self-devotion, continuous work and self-renewal. One of the most important factors for teachers to love their professions is the fact that they love the group, who they shall work with, i.e. the children (Çapa \& Çil, 2000; Erdem \& Duyan, 2011). Love of children is the basic belief of the individual in children and being with children (Baretti \& Sinsini, 1990). Loving a child is regarded one of the most accepted forms of unconditional love (Duyan \& Gelbal, 2008).

For individuals who want to choose teaching as a career (especially considering the age groups they teach, including special education, pre-school and primary school students), it is very crucial for them to like children (Gelbal \& Duyan, 2010; Erdem \& Duyan, 2011; Saltalı \& Erbay 2013; Kabaklı Çimen 2015; Kuşçu, Erbay, Acar \& Gülnar. 2015). It is significantly essential that teachers should know the society they serve ahead to avoid the burnout syndrome in performing their jobs for a long time (Yazıc1, 2013). It is indicated that liking children and taking care of them improves teachers' motivation, help them to find solutions to the issues in the classroom and make their study more enjoyable (Duyan \& Gelbal, 2008; Gelbal \& Duyan, 2010). Also, it can be a source of teachers' motivation to teach which will enable the teachers to perform their job well. 
Motivation, involving initiating and sustaining a task to be done, is the power that manipulates an individual's deeds (Recto, 2005). It involves the justifications of human acts; it is not a product but a process (Güney, 2011). Motivation is studied using two approaches: inner and external. Individual's act starts with an intention of satisfying his or her interest and curiosity without any external interventions; this is the inner motivation (Argon \& Cicioglu 2017). If teacher candidates say being a teacher is their target, they like to teach, like children, find teaching enjoyable and fun and want to have remarkable influence in the lives of youths/children, that means they have inner motivation towards their careers. External motivation involves the facilities provided by organizations to improve work performance of workers. It moves along the motivators and inspirers such as rewards and punishment (Argon \& Cicioğlu 2017). These means are concrete and include factors like being satisfied with the work environment, being respected by others, making a good impression on students' families, equal pay, salary increment, promotion, merit based rise, additional benefits and job security (Malmberg, 2006; Dereli İman 2014). In other words, individual only includes the action profits not the action. It causes an individual to act in line with the inspirers and deterrents (Hoy \& Miskel, 2010; Ayık \& Ataş 2014).

From the view point of teachers, motivation affects their reserved time set aside for their jobs, students and self-developments, the quality of their engaging in work and their willingness to work (Argon \& Cicioğlu 2017). Here, teaching motivation is as important as teaching skills. Teachers with inner teaching motivation choose teaching related activities, face and handle difficulties patiently and persistently without expecting any profits in return (Kauffman, Yilmaz Soylu \& Duke, 2011). Also, they are eager for the materialization of educational reforms and implementation of the modifications (Yazic1 2009). In a sense, those efforts exerted by teachers to improve their performance and show professional developments are also related to their teaching motivations (Butler, 2007; Watt and Richardson, 2007; Uzel Candan \& Evin Gencel, 2015; Argon \& Cicioğlu 2017). Students' motivation and quality of education are also extensively related to teaching motivation (Argon \& Cicioğlu 2017). Due to their low motivations, teachers who fail to maintain their success and satisfaction have high level of stress (Yazıc1, 2009; Ajayi, Lawani \& Salomi, 2012). Motivation is needed for them to effectively manage the learning/ teaching process. The motivations of teacher candidates and teachers are a significant element that accompanies their willingness to work, having relationships with students, planning, setting and implementing the learning and teaching process.

On the other hand, the self-efficacy beliefs of teachers and teacher candidates in developing their teaching motivations are very important factors (Fritz, Miller-Heyl, Kreutzer \& MacPhee, 1995; Schiefele \& Schaffner 2015; Wang, Hall, \& Rahimi 2015; Skaalvik, \& Skaalvik, 2017). Self-efficacy beliefs closely affect teachers' performances in the classroom. A teacher who has a strong self-efficacy belief is more eager to teach and can create an effective atmosphere of education (Holzberger, Philipp \& Kunter, 2013; Klassen, \& Tze, 2014; Aldridge, \& Fraser, 2016). Teachers and teacher candidates with self-efficacy beliefs that they have teaching skills create an effective atmosphere of education (Akkoyunlu, Orhan \& Umay 2005; Demirtaş, Cömert \& Özer 2011).

Bandura $(1994,1997)$ defines self-efficacy as a person's confidence in his or her skill in order to accomplish a specific task; individuals' judgments about organizing and realization of predetermined work, task and activities. It also means self-related beliefs of an individual's capacities to disclose his or her attitudes and skills against life related situations. Concerning their self-efficacy beliefs, the following questions are asked: 'can I write very well?', 'can I drive car?', 'can I sort this problem out?' (Pajares \& Schunk, 2001). Responses to these questions will reveal the individual's level of self-confidence in accomplishing a job or completing an activity with success (B1kmaz, 2004). Briefly, self-efficacy can be summarized as an individual's' beliefs related to his or her skills in accomplishing a job (Ilgaz, 2011).

Self-efficacy beliefs determine the amount of effort that will be expended when coping with an activity, how long the individual will persist in the face of obstacles and how the individual can be flexible in unfavorably conditions. An individual with higher self-efficacy can expend higher efforts, persistency, flexibility and self-confidence as well. Naturally, this reflects in their behaviors leading to better performance in their field of study (Pajares, 1996; Bandura, 1997; Bandura 2001).

Teachers' self-efficacy helps students with special need and students with low learning motivation; their beliefs affecting their potential capacities (Bandura 1997; Akkoyunlu, Orhan \& Umay 2005). Teachers are posed with this question, 'Can I plan and implement the ideas and actions required to accomplish my tasks?' (Demirtaş, Cömert \& Özer 2011). In line with the answer of this question, teachers' self-efficacy belief is a critical factor that determines their attitudes towards innovations and changes, the efforts to meet their requirements, their learning and teaching motivations, the creation of a positive classroom atmosphere, the preparation of education environment to sustain the development areas of students, the quality of classroom practices and the methods and strategies used in education (Woolfolk \& Hoy, 1990; Woolfolk, Rosoff \& Hoy, 1990; Demirtaş, Cömert \& Özer 2011). Apart from these, these beliefs help teachers with the kind of classroom atmosphere they will create, how they will manage it, what their tendencies will be towards difficult students and with a special need and making estimates of how long they will carry on with teaching (Schunk, 1985; Bandura 1997; Akkoyunlu, Orhan \& Umay 2005; Skaalvik \& Skaalvik, 2010; Demirtaş, Cömert \& Özer 2011). Concisely, 
teachers' self-efficacy affects their prospective behaviors. It reveals what they feel and think of teaching, their emotional reactions and how to get themselves self-motivated (Bandura, 1994).

The participants studying at Faculty of Education are teachers of the future. Therefore, it is vital that the teacher candidates who go for this career should have a desirable level of sensitivity level towards the people they will serve and the profession they will engage in. Accordingly, teacher candidates must have a good attitude to like a citizen from birth through the end of adolescence (an individual below 18 years old), concisely that is a child (Gelbal \& Duyan, 2010). Besides, teacher candidates' motivation to teach may modify their attitudes, perceptions and behaviors associated with their job. Can a profession influence an individual's life to a great extent, especially teaching? Providing teacher candidates with high levels of inner teaching motivation will be an advantage to the educational institutions; they will get teachers who are eager to perform and well aware of their responsibilities, embrace their job entirely and put in more effort (Argon \& Ciciloğlu 2017).

Primary school teaching, preschool and special education departments in Faculties of Education have a relatively distinctive status in terms of working together and implementing and adapting learning-teaching processes. Working together with these groups necessitates relatively more dedication, time, patience, effort and enthusiasm to study in this field. Moreover, their ability to meet the expectations of families is another unique significance of these groups. The quality of education submitted in these groups is bounded by the teacher to the greatest extent. The behaviors and deeds teachers exhibit directly affect the students in the classroom. Teacher is the most important role model for these groups. Additionally, teacher, student, school curriculum, educational environment, and management, family and the community are all the parts of the interaction (Gelbal \& Duyan, 2010). Teachers take part efficiently within the functionality of this existing structure and mostly manage the process. Therefore, it is distinctly important to reveal the personal qualities of teacher candidates, their abilities in the learning and teaching process, their motivation levels and self-efficacy beliefs. The outcomes will be beneficial in the assessment of teacher candidates' existence status and modifying process in accordance. Therefore, it has been decided in the present study to comparatively examine the primary school teacher, preschool and special education departments.

When their special conditions and age groups are examined, the teachers who the children first encounter and mostly care for are preschool, special education and class teachers. These three teacher groups play an important role in development of children. The school experiences of children in that period and the communication which they establish with their teachers shape their self-concept, personality, achievement motivation, habits and value judgments (Çay \& Şanal 2016). Teacher education in those three fields should not be left to chance. Therefore, it has a particular importance to determine the personal features of preservice teachers studying at those departments related to students and classroom environment, their levels of loving children, the self-efficacy beliefs and motivation levels which they perceive related to learning and teaching processes and to reveal the relationships between them.

Loving a child (Gelbal \& Duyan 2010; Yazıc1, 2013; Dereli İman, 2014; Kaynak et al., 2015; Çay \& Şanal 2016), self-sufficiency beliefs (Gürbüztürk \& Şad, 2009; Durdukoca, 2010; Demirtaş, Cömert \& Özer 2011; Karahan \& Uyanık Balat, 2011; Yenice 2012; Nakip \& Özcan, 2016), and teaching motivation in Turkey (Argon \& Ertürk 2013; Ay1k \& Ataş 2014; Çelik \&Terzi 2017; Argon \& Cicioğlu 2017) were examined on preservice teachers who studied at different departments. However, when the literature was examined, no study was encountered, in which those three groups were evaluated together comparatively in terms of loving a child, self-sufficiency beliefs and teaching motivation. Additionally, according to the literature, as compared with the other two departments, it was seen that no study was carried out, in which those subjects were studied with special education preservice teachers. In this regard, the emerging results are hoped to contribute to the evaluation of the existing conditions of preservice teachers studying in these fields, revealing how effective the programs educating teachers in those fields are. Especially the special education department in the study group has started to produce graduates for two years. The results belonging to that department shall be an important source for development of special education teaching and evaluation of its programs.

Therefore, this research aims to reveal the level of affection for children, teaching motivations and self-efficacy beliefs of teacher candidates studying at special education, preschool and primary school teacher departments based on their gender, class and departments and to examine the correlations among their liking levels, self-efficacy beliefs and teaching motivations.

\section{Method}

\subsection{Research Model}

In this research, the relational screening model that is one of the general screening models was used to examine the prevalence and/or volume of combined variations among multiple variables (Büyüköztürk, Kılıç-Çakmak, Akgün, Karadeniz \& Demirel, 2014). 


\subsection{Population and Sample}

The preservice teachers, who have studied at Special Education, Preschool and Primary school teacher departments at the Faculty of Education of a state university located in Izmir province in Turkey, form the population of the present study. The criterion sampling method, one of the purposeful sampling methods, was used for determining the study group. The basic sense in the criterion sampling is to study all the conditions which correspond to a series of pre-determined criteria. The mentioned criterion or criteria can be formed by the researcher or a formerly prepared list of criteria can be used (Yıldırım \& Şimşek, 2011). In determination of preservice teachers who participated in the study within the scope of the present study, the fact that the preservice teachers, who studied at special education, preschool and classroom teaching departments, became the second and fourth-year year students, the 4th year students took the course "Teaching Practice" and they voluntarily filled in the scales for the present study was taken as criteria.

The study group was determined as the 2nd and 4th years (grades) in order to reveal the preservice teachers' loving a child, self-sufficiency beliefs and teaching motivation during the first year and the last year of the university and to detect the differences between them. Preservice teachers take very few courses related to their fields during the 1 st year. Therefore, instead of 1st-year students, the data were collected from the 2nd-year preservice teachers. During the 4th year, preservice teachers take the teaching practice course and interact with the group, which they shall work with, and they give sample lessons.

\subsubsection{The Study Group}

In this regard, the present study was carried out in the 2017-2018 academic year with 368 preservice teachers, who studied at the Faculty of Education at a state university located in Izmir province in Turkey. Of the preservice teachers participating in the study, 179 are $2^{\text {nd }}$-year students $(48.6 \%), 189(51.4 \%)$ are the 4th-year students, $100(27.2 \%)$ are male and $268(72.8 \%)$ are female. 108 of the participants (29.3\%) study at special education teaching, $136(37.0 \%)$ of them study at classroom teaching and $124(33.7 \%)$ of them study at preschool teaching department. The scales were applied to all the $2^{\text {nd }}$ and $4^{\text {th }}$-year students who were at the course and volunteered for participating in the studies on the day, on which the scales application was carried out. 6 special education and 3 preschool preservice teachers, who filled in the scales incompletely, were not included into the study.

\subsection{Application of Data Collection Tools}

Before starting to apply the scales, the necessary permissions were received from the relevant units of the university. Later, planning was done and interviews were held with instructors at the class hours. The scales were applied by the researcher to the preservice teachers in the classroom environment. The volunteers, who wanted to fill in the mentioned scales, were included into the application. The applications lasted for twenty-twenty five minutes.

\subsection{Data Collection Tools}

Data were collected by means of 'Barnett Liking Children, Teaching Motivation and Teachers' Self- Efficacy Beliefs Scales'.

\subsubsection{Barnett Liking of Children Scale}

'Barnett Liking Children Scale' developed by Barnett and Sinsini (1990), and adapted in Turkish by Duyan \& Gelbal (2008) is used to measure teacher candidates' affection for children status. In the scale, there are 14 points prepared in a 7- point likert type. Cronbach Alpha coefficient of the scale is 0.92 , and the test-retest correlations are 0.85 . The structural validity of the scale was tested by the explanatory analysis and correction factor. In processing of the explanatory analysis, a single factor structure was obtained clarifying the $60.98 \%$ of the total variance. In the correction factor analysis, it was determined that this model was well adapted. The scores in the scales vary between 14 and 98 . The higher scores refer to higher level of affection for children while lower scores refer to lower levels of affection for children (Duyan \& Gelbal, 2008).

\subsubsection{Teachers' Sense of Efficacy Scale}

Teachers' Sense of Efficacy Scale developed by Tschannen-Moran \& Hoy (2001), and adapted in Turkish by Çapa, Çakıroğlu \& Sarıkaya (2005) is used to collect the data corresponding to the teacher candidates' self-efficacy. Within the scale the rating varies between 1 and 9 exhibiting the quantifiers as not enough, little enough, enough to some extent, quite enough and more than enough. Teachers' Sense of Efficacy Scale consists of a 9- point Likert type, 24 points and 3 subscales. For the sub dimensions of the scale the following samples are given; 'How good are you to motivate students to pay attention to lessons? Students' participation, 'How can you assess whether students comprehend what you teach? (educational strategies), 'How can you control all the behaviors affecting the lesson inadvertently?' (Class management). For these subscales Cronbach Alpha reliability coefficients are as follows; self-efficacy for students' participation is 0.82 , self-efficacy of educational strategies is 0.86 , self-efficacy of class management is 0.84 . The reliability coefficient of the entire scale is 0.93 . 


\subsubsection{Motivation to Teach Scale}

Motivation to Teach Scale developed by Kauffman, Yllmaz-Soylu \& Duke (2011) is used to analyze the teacher candidates' inner and external motivations to teach. The scale was adapted into Turkish by Ayık, Ataş Akdemir \& Seçer (2015). The scale is a measurement tool with two dimensions: inner and external motivation; 5 point- Likert type constitutes 12 points. The higher scores from the scale refer to the higher levels of teaching motivation while the lower scores refer to lower levels of teaching motivation. The results of explanatory factor analysis established that the scale was expounded as \%52,41variance in two dimensions and according to second degree DFA results in the correction factor analysis. This two dimension structure was well adapted $(\mathrm{RMSEA}=0.064, \mathrm{RMR}=0.010, \mathrm{NFI}=0.95, \mathrm{NNFI}=0.96$, $\mathrm{CFI}=0.97, \mathrm{IFI}=0.97, \mathrm{RFI}=0.93, \mathrm{AGFI}=0.90, \mathrm{GFI}=0.94$ ). The reliability analyses of the scale for inner consistency coefficient yield $\alpha=0.86$ and the test-retest reliability yields. 81 .

\subsection{Data Analysis}

The data of 368 teacher candidates were assessed. In processing the data, SPSS 22 statistical programs were used. Ttest was applied to establish the relations among self-efficacy, liking children and teaching motivation based on gender, and class of the teacher candidates. One way variance analysis was conducted based on the teachers' department variables. Before data analysis, the variables of the data were primarily examined to check if the data met the assumption of normality. The findings are established as follows: mean, mode and median are close to other, the skewness and kurtosis coefficients are close to 0 within \pm 1 limit, and the relative valence factor quoting the ratio between the standard deviation and mean as percentage is between 20 and 25 (Tabachnick \& Fidell, 2013). Thus, ratifying the distribution as normal within the study, the linear regression analyses were conducted. In order to determine the prediction of self-efficacy and motivation to teach for liking children, the linear regression analysis was applied on the self-efficacy and motivation to teach (predictor variable) and liking children (dependent variable). Before the data analyses, assumptions of multiple linear regression were examined. For this purpose, the correlation among the predictor variables, tolerance and VIF values was also examined. The correlation among the predictor variables is over $\mathrm{r}>$, 90, VIF value is equal or over 10 and tolerance value is lower than .10; this means there is multiple linear correlation (Çokluk, Şekercioğulu \& Büyüköztürk, 2010). The correlation levels among predictor variables are .59 and .08. As for tolerance values, they vary between .25 and .64, while VIF values are between 1.55 and 3.09. These results show that the data meet the assumptions of multiple linear regression.

\section{Findings}

The levels of liking children, teaching motivations and self-efficacy beliefs of the teacher candidates studying in special education, pre-school and primary school teacher departments are determined. There are differences between these levels based on gender, and classroom variables; there are correlations between the variables of departments and levels of liking children, self-efficacy beliefs and motivations to teach. The mean, standard deviation values, the highest (maximum) and lowest (minimum) scores correspond to teacher candidates' levels of liking children, motivation to teach and self-efficacy (Table 1).

Table 1. Teacher Candidates' Self Efficacy to Teach, Motivation to Teach and Liking Children Scores Distribution

\begin{tabular}{lccccl}
\hline Sub Dimensions & $\mathrm{n}$ & Minimum & Maximum & Mean & Sd \\
\hline Class Management & 368 & 20 & 72 & 54.88 & 8.41 \\
\hline Educational Strategies & 368 & 19 & 72 & 55.70 & 8.52 \\
\hline Student Participation & 368 & 11 & 72 & 55.58 & 8.27 \\
\hline Inner Teaching Motivation & 368 & 6 & 30 & 20.60 & 4.42 \\
\hline External Teaching Motivations & 368 & 6 & 30 & 18.79 & 4.44 \\
\hline Liking Children & 368 & 37 & 98 & 85.31 & 12.33 \\
\hline
\end{tabular}

The average score of the teacher candidates for liking children is 85.31. This result shows that the level of liking children for the teacher candidates is high. Also, the teacher candidates' average scores for external motivation to teach is 18.79 and the inner motivation to teach is 20.60 . The average of inner motivation to teach is higher than the external motivation to teach. From these results, it may be specified that the external and inner motivation to teach is over average value. Examining the subdivisions of self-efficacy, the results are as follows: for teacher candidates the average score of class management is 54.88, the average score of educational strategies is 55.70 and the average score of students' participation is 55.70. The teacher candidates' self -efficacy subdivisions is over average value. Briefly, it is clear that the teacher candidates like children and they desire to be teachers only due to inner factors but also external factors even; the ratio between both is not high. Also, they have sufficient capacity to manage their class, can use 
educational strategies in classroom and make students to participate. The scores of teacher candidates' self-efficacy, motivation to teach and liking children based on gender distribution and t-test results are shown in Table 2.

Table 2. Teacher candidates' self-efficacy motivation to teach and liking children in terms of gender distribution and t-test results

\begin{tabular}{llcccccc}
\hline Sub dimensions & Gender & $\mathrm{n}$ & Mean & Sd & Df & t & P \\
\hline Class Management & Male & 100 & 54,69 & 8,79 & 366 & -.26 & .80 \\
& Female & 268 & 54,94 & 8,27 & & & \\
\hline Educational Strategies & Male & 100 & 55,00 & 8,92 & 366 & -.96 & .34 \\
& Female & 268 & 55,96 & 8,37 & & & \\
\hline Participation to Learn & Male & 100 & 54,66 & 8,43 & 366 & -1.31 & .19 \\
& Female & 268 & 55,93 & 8,20 & & & \\
\hline Inner Teaching Motivation & Male & 100 & 20,56 & 4,60 & 366 & -.11 & .92 \\
& Female & 268 & 20,62 & 4,35 & & & \\
\hline External Teaching Motivation & Male & 100 & 19,19 & 4,53 & 366 & 1.07 & .29 \\
& Female & 268 & 18,63 & 4,40 & & & \\
\hline Liking Children & Male & 100 & 83,40 & 12,12 & 366 & -1.82 & .07 \\
& Female & 268 & 86,03 & 12,35 & & & \\
\hline
\end{tabular}

In Table 2, the average scores of class management, educational strategies, students' participation, self-efficacy beliefs, inner teaching motivation and liking children for female teacher candidates are higher than those of the male candidates. As for external teaching motivation, male teacher candidates' scores are higher. T test results show there is no significant differences between the averages. Teacher candidates' self-efficacy, motivation to teach and liking children based on class distribution and t-test results are shown in Table 3.

Table 3. Teacher candidates' self-efficacy, motivation to teach and liking children in terms of attending class distribution and t-test results

\begin{tabular}{llllllll}
\hline Sub dimensions & Grade & $\mathrm{n}$ & Mean & $\mathrm{Sd}$ & $\mathrm{Df}$ & $\mathrm{t}$ & $\mathrm{P}$ \\
\hline Class Management & 2 & 175 & 53,98 & 8,88 & 366 & -1.95 & .05 \\
& 4 & 193 & 55,69 & 7,89 & & & \\
\hline Educational Strategies & 2 & 175 & 54,02 & 8,97 & 366 & -3.64 & $.00^{*}$ \\
& 4 & 193 & 57,21 & 7,80 & & & \\
\hline Participation to Learn & 2 & 175 & 54,93 & 8,35 & 366 & -1.45 & .14 \\
& 4 & 193 & 56,18 & 8,18 & & & \\
\hline Inner Teaching Motivation & 2 & 175 & 20,33 & 4,42 & 366 & -1.11 & .26 \\
& 4 & 193 & 20,84 & 4,41 & & & \\
\hline External Teaching Motivation & 2 & 175 & 18,75 & 4,29 & 366 & -.12 & .89 \\
& 4 & 193 & 18,81 & 4,57 & & & \\
\hline Liking Children & 2 & 175 & 84,55 & 12,94 & 366 & -1.12 & .26 \\
& 4 & 193 & 86,00 & 11,74 & & & \\
\hline
\end{tabular}

In Table 3, the average scores of class management, educational strategies, participation in learning, self-efficacy beliefs, inner teaching motivation and liking children for 4th grade teacher candidates are higher than those of 2nd grade teacher candidates. However, except for the educational strategies, self-efficacy beliefs, the rest of the averages exhibits non-significant differences. The scores of educational strategies, self-efficacy beliefs for 4th year teacher candidates higher [t $(366)=-3.64, p<.05]$ than those of the 2nd year. Accordingly, they have efficient capacity for using the educational strategies in the classroom.

The results of variance analysis showing whether the average scores of teacher candidates' self-efficacy belief, motivation to teach and liking children differ in terms of department variables are shown in Table 4. 
Table 4. Teacher candidates' self-efficacy, motivation to teach and liking children scores in terms of department distribution and $\mathrm{F}$ Test results

\begin{tabular}{llccccc}
\hline Sub dimensions & Department & $\mathrm{n}$ & Mean & Sd & $\mathrm{F}$ & $\mathrm{P}$ \\
\hline Class Management & Special Education & 108 & 54,64 & 6,73 & 2,52 &, 08 \\
& Class & 136 & 56,07 & 8,00 & & \\
& Preschool & 124 & 53,77 & 9,91 & &, 24 \\
\hline Educational Strategies & Special Education & 108 & 55,78 & 6,51 & 1,41 & \\
& Class & 136 & 56,51 & 7,94 & & \\
& Preschool & 124 & 54,73 & 10,43 & &, 57 \\
\hline Participation in & Special Education & 108 & 55,34 & 5,92 &, 55 & \\
Learning & Class & 136 & 56,17 & 7,52 & &, 94 \\
& Preschool & 124 & 55,15 & 10,54 & &, 06 \\
\hline Inner Teaching & Special Education & 108 & 20,49 & 4,69 & & \\
Motivation & Class & 136 & 20,60 & 3,89 & & \\
& Preschool & 124 & 20,69 & 4,74 & & \\
\hline External Teaching & Special Education & 108 & 19,01 & 4,07 & 1,75 & \\
Motivation & Class & 136 & 18,22 & 4,43 & & \\
& Preschool & 124 & 19,14 & 4,71 & & \\
\hline Liking Children & Special Education & 108 & 86,14 & 11,07 & 1,38 & \\
& Class & 136 & 86,02 & 12,25 & & \\
& Preschool & 124 & 83,81 & 13,38 & & \\
\hline
\end{tabular}

In Table 4, the average scores of class management, educational strategies, participation in learning, self-efficacy beliefs for the teacher candidates are higher than those of others. The average scores of inner teaching motivation sub dimensions for preschool teacher candidates are higher than those of class and special education teacher candidates. The highest average scores for special education teacher candidates are from liking children. The lowest average scores of external motivation sub dimension are from class teacher candidates. However, F test results yielded non-significant differences between the averages of self-efficacy belief and motivation to teach in terms of departments and liking children.

The average deviation values for sub dimensions of Teacher Self -Efficacy Scale, Teacher Motivation Scale and Liking Children Scale used in this research are shown in Table 5, as well as Pearson correlation coefficients for examining correlations among the variables.

Table 5. Correlations

\begin{tabular}{|c|c|c|c|c|c|c|}
\hline Variables & 1 & 2 & 3 & 4 & 5 & 6 \\
\hline 1. Class Management & & & & & & \\
\hline 2. Educational Strategies & $.83 * *$ & & & & & \\
\hline 3. Student Participation & $.83 * *$ & $.85^{* *}$ & & & & \\
\hline 4. Inner Teaching Motivation & $.16^{*}$ & $.21 *$ & $.19 *$ & & & \\
\hline 5. External Teaching Motivation & $.12 *$ & $.11 *$ & .09 & $.59 *$ & & \\
\hline 6. Liking Children & $.24 *$ & $.32 *$ & $.40^{* *}$ & $.28 *$ & .08 & \\
\hline
\end{tabular}

$* * \mathrm{p}<.01, * \mathrm{p}<.05$

Examining the correlation coefficients, it is clearly seen that there is a moderate significant and positive correlation among liking children, students' participation, self- efficacy $(\mathrm{r}=.40, \mathrm{p}<.01)$ and educational strategies subdimensions $(\mathrm{r}$ $=.32 \mathrm{p}<.05)$. There are low significant and positive correlations between liking children and inner motivation $(\mathrm{r}=.28$, $\mathrm{p}<.05)$ and class management and self- efficacy beliefs $(\mathrm{r}=.24, \mathrm{p}<.05)$. There is a non-significant correlation between liking children and external motivation $(\mathrm{r}=.08, \mathrm{p}>.05)$. 
SPSS 22 program is used to make multiple regression anaysis to determine the candidates' liking children as predictor variables. In the analysis, liking children is defined as a dependent variable, educational strategies, students' participation, inner and external motivations are defined as independent variables. The results are given in Table 6.

Table 6. The predictor variables in terms of multiple linear regression analysis

\begin{tabular}{llcccl}
\hline Variables & $\beta$ & $\mathrm{F}$ & $\mathrm{R}$ & $\mathrm{R}^{2}$ & $\mathrm{t}$ Value \\
\hline Class Management & -.29 & 22.77 & .49 & .23 & $-3.20^{*}$ \\
Educational Strategies & .00 & & & & .01 \\
Students' Participation & .60 & & & & $6.28^{*}$ \\
Inner Teaching Motivation & .27 & & & $4.67^{*}$ \\
External Teaching Motivation & -.10 & & & -1.78
\end{tabular}

In examining the result of multiple linear regression analysis data, it is clearly seen that the independent variables predict liking children significantly $[\mathrm{F}(5,367)=22.77, \mathrm{p}<.01]$. Independent variables may account for $23 \%$ of liking children. The results of t-Test corresponding to significance of regression coefficients, students' participation, self-efficacy belief $(\beta=.60, \mathrm{t}=6.28, \mathrm{p}<.01)$, inner teaching motivation $(\beta=.27, \mathrm{t}=4.67, \mathrm{p}<.01)$ and class management self-efficacy $(\beta=-.29, \mathrm{t}=-3.20, \mathrm{p}<.01)$ are seen as the significant predictor of liking children. The educational strategies self- efficacy $(\beta=.00, t=0.1 \mathrm{p}>.05)$ and external motivation to teach $(\beta=-.10, \mathrm{t}=-1.78, \mathrm{p}>.05)$ have non-significant beneficial impacts. It is clearly seen that students' participation self-efficacy and inner motivation to teach predict liking children significantly and positively; class management and self-efficacy belief predict it negatively. In line with the obtained results, teacher candidates with high levels of students' participation, self-efficacy belief and inner motivation to teach can be specified as having higher levels of affection for children.

\section{Discussion and Conclusion}

In this research, the predictive strength is examined for the levels of self-efficacy beliefs, motivation to teach and liking children based on teacher candidates' class level, department and gender along with the levels of teacher candidates' self-efficacy beliefs and motivations to teach. In accordance with the findings produced at the end of this research, teacher candidates like children. The female preservice teachers' levels of loving a child are higher than those of the male preservice teachers but this difference is not significant. When the literature is examined, it shows consistency with the studies, in which Gelbal \& Duyan (2010) determined that primary school teachers' levels of loving a child did not differ by gender significantly, in which Durualp \& Unal (2013) determined that preschool teachers' levels of loving a child did not differ by gender significantly and in which Aksoy \& Baran (2011) determined that preservice classroom teachers' levels of loving a child did not differ by gender significantly. However, in the literature also, there are studies that show that the levels of liking children for female teacher candidates are significantly higher for the following candidates; preschool teacher candidates (Arslan, Pınarcık, Ergin \& Kaynak, 2013; Yazıc1, 2013; Dereli İman, 2014; Kaynak, Ergin, Arslan \& Pınarcık, 2015), class teacher candidates (Özkara, 2013), different departments teacher candidates, active service teacher candidates (Kabaklı Çimen, 2015), social studies and primary school teacher candidates (Faiz, Körükcü \& Karadeniz, 2016).

In this research, it is determined that non-significant difference exists between the levels of liking children for teacher candidates based on departments. Teacher candidates from the three departments like children. This result is similar with the following research results on liking children based on teacher candidates' department: preschool (Yazıc1 2013; Saltalı \& Erbay 2013; Dereli İman, 2014; Kabaklı Çimen 2015; Durualp \& Kaytez 2016) and primary school teacher (Çay \& Şanal 2016).

In general, as the results of these two facts are assessed, it is favorable that there are no differences among both female and male teacher candidates and departments in terms of liking children. It is pleasant that both female and male teacher candidates like children in terms of their studying groups. Female and male teacher candidates in this research group like children. Because the female and male preservice teachers in the study group are very likely to work as teachers in the state and private institutions when they have graduated. Apart from this, this love is an indicator of the fact that they have a positive attitude towards children (Kuşçu et al., 2015; Kabaklı \& Çimen, 2015). It is also a significant that the teacher candidates are eager to teach and establish relationships with their students in the teaching/learning processes. Loving child is inevitable to obtain quality and successful education (Gelbal \& Duyan, 2010; Yazıc1, 2013; Dereli İman, 2014). On the other hand, as the levels of liking children are high for teacher candidates of special education, preschool and primary school, it also means that they adopt the studying groups and have tendencies (Gelbal \& Duyan, 2010) to teach.

According to other findings, the levels of liking children for 4th year teacher candidates are higher than those of the 2nd year candidates, but non-significant differences were determined. In literature, there are other reviews showing that the 
levels of liking children for 4th year teacher candidates are higher than those of others (Yazic1, 2013; Dereli İman, 2014; Kaynak, Ergin, Arslan \& Pinarcik 2015). Teacher candidates take intensive practical classes especially those in $3^{\text {rd }}$ and $4^{\text {th }}$ years within the four years education period. Naturally, they start by identifying the group studying together and establishing closer relationships with them. Therefore, the averages of $4^{\text {th }}$ year teacher candidates are higher. Interacting with children and studying together promotes the level of liking children. Review developed by Cay \& Sanal (2016) also validates this fact. Cay \& Sanal (2016) determined in another review that the levels of liking children are higher for primary school teachers in active service than teacher candidates.

In this research, teacher candidates think they can manage their class, apply educational strategies in classroom and make students to participate in class. Class management, educational strategies and participation in learning, self-efficacy beliefs of the female teacher candidates are higher than those of the males; however non-significant differences were found. In the literature, there are other studies parallel to this research findings, such as Gencer \& Cakıroğlu (2007); Ekici, (2008); Karahan \& Uyanık Balat (2011); Yenice (2012); Nakip \& Özcan, (2016); but also other reviews reveal that females' average scores were higher than those of the males (Çapri \& Çelikkaleli, 2008; Özdemir, 2008; Demirtaş, Cömert \& Özer, 2011) and males higher than females (Morgil, Seçken \& Yücel, 2004; Durdukoca, 2010; Korkut \& Babaoğlan, 2012) in terms of their self-efficacy beliefs .The cause of that differentiation by gender can arise from the personal features and individual experiences of the preservice teachers in the groups studied. The relevant successful experiences lead to the positive self-efficacy and unsuccessful experiences the negative self-efficacy (Bandura, 1997). According to the results of the study carried out, it is stated that the strongest and permanent belief source is the individual experiences (Bandura, 1997; Bandura, 2001). In general, there are no differences determined in terms of both genders, because, both groups have high potential for being teachers. Here, the critical thing is that self-efficacy beliefs in terms of sub dimensions are high for both groups. Teachers with high self-efficacy belief concentrate on educational activities more intensively during class, are more caring, support both normal students and those with special needs, are eager to continue with academic standards and implement innovative techniques (Tabancalı \& Çelik 2013). They are positive and create good learning atmosphere in the classroom (Bandura, 1993). Additionally, they spent longer time in teaching. However, teachers with low level self-efficacy belief spend most of their time with non-academic issues, easily ignore the students who are eager to learn (Dadand, Kalyon \& Yazıc1 2016) and cannot face challenges in their professions.

4th year teacher candidates utilized educational strategies more than 2nd year teacher candidates; there are significant differences between educational strategies and self-efficacy beliefs. These results are similar to the studies of Altunçekiç, Yaman \& Koray (2005), Gerçek, Yılmaz, Köseoğlu \& Soran (2006), Kozcu Çakır \& Senler (2007) and Durdukoca, (2010). The higher level of the $4^{\text {th }}$ year teachers' educational strategies and self-efficacy beliefs for may stem from they having more practical and educational classes and spending more time doing practical. On the other hand, the reasons for the non-significant differences between class management and students' participation are as follows; more of practical teachers, spending less intensive time with class alone, and facing unpleasant experience during practical. In this context, the subjects of practical classes should be questioned.

In this research, it was revealed that there were non-significant differences between teacher candidates' class management, learning participation, self-efficacy beliefs based on departments. Yenice (2012), Güven \& Gökdağ Baltaoğlu (2017) determined that the teacher candidates' studying departments caused non-significant differences in self-efficacy beliefs. There are studies that show there are significant differences between self-efficacy beliefs and departments (Akgün 2013; Bakaç \& Özen 2016; Kabaran, Altıntaş \& Kabaran 2016; Donmuş, Akpunar \& Eroğlu 2017). But, it is seen that these differences mostly correspond to Turkish, Social Sciences and Mathematics teaching and other fields related (Çakır, Kan \& Sünbül, 2006; Gürbüztürk \& Şad, 2009; Demirtaş, Cömert \& Özer 2011). Accordingly, the results of these outcomes are as follows; same situations for each student of the three departments within classes and applications.

The levels of inner and external teaching motivation are over average value for teacher candidates. However, inner motivation average is higher than external teaching motivation for teacher candidates. Similar results may be seen in the studies completed by Dereli \& Acat (2010), Ayık \& Ataş (2014), Güzel Candan \& Evin Gencel, (2015). Accordingly, teacher candidates desire to be teachers and are motivated to teach not only by inner factors alone but also external factors. Inner and external teaching motivation levels do not differ in terms of teacher candidates' gender, studying department and class. Briefly, there are no differences on being a teacher and teaching between female and male teacher candidates studying at $2^{\text {nd }}$ and $4^{\text {th }}$ years of special education and primary school teacher departments. Studies similar to these results include those of Argon \& Ertürk (2013), Argon \& Cicioğlu (2017) and Çelik \& Terzi (2017); those differing from these results include of Acat \& Yenilmez (2004) and Dereli İman (2014). Teacher candidates frequently go for teaching willingly and passionately considering the decent satisfaction in return and other efficient things; they usually have a lot of job opportunities, are easily hired and have the chances to be assigned to any state institutions. 
Apart from these, it has been determined that there are moderate positive and significant differences between liking children and students' participation with education strategies and self-efficacy beliefs. It is also detected that there are moderate positive and significant differences between inner teaching motivation and class management and self-efficacy beliefs.

It is determined that teacher candidates' participation and self-efficacy beliefs and inner teaching motivations predicted liking children positively and significantly; class management and self-efficacy beliefs predicted liking children negatively and significantly based on the application of the linear regression analysis results.

In other words, teacher candidates, who encourage children to be involved in school activities to boost their self confidence want to teach due to inner factors and have higher levels of liking children. This result supports the study findings, which show that self-efficacy beliefs affect the teaching motivation and the level of caring for students (Butler \& Shibaz, 2014; Aloe, Amo, \&Shanahan, 2014; Wang, Hall and Rahimi 2015; Schiefele \& Schaffner, 2015; Skaalvik, \& Skaalvik, 2017) and reveal that the best predictor of internal motivation is the self-efficacy level (McGeown et al. 2014). However, teacher candidates who think they can manage their class have surprisingly lower levels of liking children. Consequently, teacher candidates in this group may be considered as being willing and strict in class management.

Dereli Iman (2014) determined that liking children scores predicted inner and outer motivations corresponding to teaching profession positively and significantly. Kuşcu, Erbay, Acar \& Gülnar (2015) say that teacher candidates' attitudes towards teacher profession predicted their status of liking children. Durualp \& Kaytez (2016) detected that the higher the level of liking children, the higher job satisfaction the preschool teachers have. Saltalı \& Erbay (2013) established that preschool teachers' liking children status predicted speaking, listening and empathy skills during communication with children. Uğurlu (2013) defined that teachers' communication skills and empathic tendencies of liking children levels predicted their affection for children. These results sustained the research findings in terms of emphasizing the importance of liking children and defining the impact ranges.

\section{Recommendations}

For teacher candidates, the reasons for liking children or group consisting of children have been repeated one more time in this research. Considering their age groups and characteristics, individuals who like children should take part in special education, preschool and primary school teaching departments. Liking children is a resourceful motivator for teacher candidates in these departments. Therefore, the opportunities should be created for teacher candidates to establish a bond with the associated group by meeting in advance. Therefore, the preservice teachers should be enabled to take part actively in associations and municipalities related to the group, which they shall work with, and in different projects and activities developed by the department, at which they study. Fostering this action, teacher candidates should participate in different projects and activities corresponding to the associated group. Furthermore, for higher inner training motivation, teacher candidates should be encouraged to go for out of class activities and involve in projects that improve their skills and intentions to become teachers. Attention should be paid to offering plenty of practice opportunities in these courses and preparing the learning environments which shall create the desire for learning and achievement. The feedbacks should be given both related to performances of the preservice teachers and in order to reinforce their beliefs in their own abilities and they should be encouraged.

It was revealed that apart from this, the $4^{\text {th }}$ year preservice teachers were at the same level as the $2^{\text {nd }}$ year preservice teachers in terms of classroom management and integrating the students into the Works. It is thought-provoking that this difference did not occur in the preservice teachers being about to graduate. Apart from this, it was revealed that the preservice teachers, who thought they could more easily integrate the students into school activities during the course, both wanted to teach and become a teacher for internal reasons, and loved the children more. Therefore, the duration of the teaching practice courses of the preservice teachers should be increased and the content of the course should be revised. Moreover, the relevant departments should pay attention to choice of practice schools. The preservice teachers should practice in the schools where they can see a teaching orientation with true and nice model practices. Apart from this, opportunities should be created for the preservice teachers to work with teachers who shall be a model/sample to them in the teaching practice course. In addition to those recommendations, the practice teachers in schools should be subjected to in-service training by the relevant departments at the Faculty of Education about how to guide to the preservice teachers in conducting those courses. Bear in mind that self-confidence of the preservice teachers shall also increase as their field knowledge and teaching skills improve. Self-confidence also increases the level of self-sufficiency.

In addition to these recommendations, a different dimension can be added to the present study carried out by planning it with the qualitative research approach. Apart from this, experimental studies can be carried out related to development of self-sufficiency beliefs and teaching motivation of the preservice teachers in these three groups. In those studies, to 
what extent the preservice teachers' levels of loving a child, their self-sufficiency and teaching motivation shall be affected by the activities/practices to be carried out can be measured.

\section{References}

Acat, B., \& Yenilmez, K. (2004). Motivation levels of education faculty students in the teaching profession. Manas University Journal of Social Sciences, 12, 125-140.

Açıkgöz, Ü. K. (2012). Effective Learning on Teaching, İstanbul: Biliş Press.

Ajayi, K. O., Lawani, A. O., \& Salomi, M. O. (2012). The influences of selfconcept and academic motivation on students' attitude to mathematics in selected secondary schools in Ogun State, Nigeria. European Journal of Scientific Research, 67(3), 444-455.

Akgün, F. (2013). Preservice teachers' web pedagogical content knowledge and relationship between teachers' perceptions of self efficacy. Trakya University Journal of Education, 3(1), 48-58.

Akkoyunlu, B., Orhan, F., \& Umay, A. (2005). A study on developing teacher self efficacy scale for computer teachers. H. U. Journal of Education, 29, 1-8.

Aksoy, P., \& Baran, G. (2011). The Examination of the Correlations between Primary School Teachers' Liking Children Status and the Oriented Sense of Acceptation-Objection by Mother-Father 10. International Primary School Education Symposium (USOS), 5-7 May 2011, Sivas

Aldridge, J. M., \& Fraser, B. J. (2016). Teachers' views of their school climate and its relationship with teacher self-efficacy and job satisfaction. Learning Environments Research, 19(2), 291-307. https://doi.org/10.1007/s10984-015-9198-x

Aloe, A. M., Amo, L. C., \& Shanahan, M. E. (2014). Classroom management self-efficacy and burnout: A multivariate meta-analysis. Educational Psychology Review, 26(1), 101-126. https://doi.org/10.1007/s10648-013-9244-0

Altuncekic, A., Yaman, S., \& Koray, O. (2005). The research on prospective teachers' self-efficacy belief level and problem solving skills. Kastamonu Education Journal, 13(1), 93-102.

Argon, T., \& Cicioğlu, M. (2017). Vocational high school teachers' levels of belief in education and motivation to teach. International Journal of Social Science, 57(1), 1-23. https://doi.org/10.9761/JASSS7108

Argon, T., \& Ertürk, R. (2013). Intrinsic motivations of primary school teachers and their perceptions of organizational identity. Educational Administration: Theory and Practice, 19(2), 159-179.

Arslan, E., Pınarcık, Ö., Ergin, B., \& Kaynak, K. B. (2013). Comparative Examination for Preschool Teachers and Preschool Teachers Candidates' Liking Children Attitudes. 2nd World Conference on Educational and Instructional Studies (WCEIS), 7-9 November, Antalya.

Ayık, A., \& Ataş, Ö. (2014). The relationship between pre-service teachers' attitudes towards the teaching profession and their motivation to teach. Journal of Educational Sciences Research, 4(1), 25-43. https://doi.org/10.12973/jesr.2014.41.2

Ayık, A., Ataş, A. Ö., \& Seçer, İ. (2015). Adaptation of the motivation to teach scale into turkish: the validity and reliability study. Current Research in Education, 1(1), 33-45.

Bakaç, E., \& Özen, R. (2016). The relationship between preservice teachers' attitudes towards instructional technology and material design course, creativity perceptions and self-efficacy beliefs. Abant İzet Baysal University Journal of Education, 16(1), 41-61.

Bandura, A. (1993). Perceived self-efficacy in cognitive development and functioning. Educational Psychologist, 28(2), 117-148. https://doi.org/10.1207/s15326985ep2802_3

Bandura, A. (1994). Self efficacy. In V. S. Ramachaudran (Ed.), Encyclopedia of Human Behavior (4,71-81). Newyork Academic Press.

Bandura, A. (1997). Self Efficacy: The exercise of control. New York: Freeman.

Bandura, A. (2001). Social cognitive theory: An agentive perspective. Annual Review of Psychology, 52, 1-26. https://doi.org/10.1146/annurev.psych.52.1.1

Barnett, M. A., \& Sinisi, C. S. (1990). The initial validation of a Liking of Children Scale. Journal of Personality Assessment, 55, 161-167. https://doi.org/10.1080/00223891.1990.9674055

Bıkmaz, F. H. (2004). Self-sufficiency beliefs. Y. Kuzgun ve D. Deryakulu. (Editors) Individual Differences in Education, Nobel Press, Ankara, 289-314. 
Butler, R. (2007). Teachers' achievement goal orientations and associations with teachers' help seeking: examination of a novel approach to teacher motivation. Journal of Educational Psychology, 99(2), 241-252. https://doi.org/10.1037/0022-0663.99.2.241

Butler, R., \& Shibaz, L. (2014). Striving to connect and striving to learn: Influences of relational and mastery goals for teaching on teacher behaviors and student interest and help seeking. International Journal of Educational Research, 65, 41-53. https://doi.org/10.1016/j.ijer.2013.09.006

Büyüköztürk, S., Kılıç-Çakmak, E., Akgün, O. E., Karadeniz, S., \& Demirel, F. (2014). Scientific research methods. Ankara: Pegem Academy

Çakır, Ö., Kan, A., \& Sünbül, Ö. (2006). The assessment of teacher profession information and non-thesis master's programs in terms of attitudes and self efficacy. Mersin University Journal of Faculty of Education, 2(1), 36-47.

Çapa, Y., \& Çil, N. (2000). The attitudes of pre-service teachers towards teaching profession with regard to different variables. H. U. Journal of Education, 18, 69-73.

Çapa, Y., Çakıroğlu, J., \& Sarıkaya, H. (2005). The development and validation of a Turkish version of the teachers' sense of efficacy scale. Education and Science, 30(137), 74-81.

Çapri, B., \& Çelikkaleli, Ö. (2008). Investigation of preservice teachers' attitudes towards teaching and professional self-efficacy beliefs according to their gender, programs, and faculties. Inönü University Journal of Faculty of Education, 9(15), 33-53.

Çay, Y., \& Şanal, M. (2016). Candidate primary school and primary school teachers'level of liking of children. Journal of Turkish Education Sciences, 4 (6), 135-142.

Çelik, H., \& Terzi, A. R. (2017). An analysis of formation teacher candidates' attitudes towards copying and their level of teaching motivation. Journal of Current Researches on Social Sciences, 7(3), 349-362. doi:10.26579/jocress-7.3.23

Çokluk, Ö., Şekercioğlu, G., \& Büyüköztürk, Ş. (2010). Multivariate statistics for the social sciences: SPSS and LISREL Applied. Ankara: PegemA Publishing

Dadandı, İ., Kalyon, A., \& Yazıcı, H (2016). Teacher self-efficacy beliefs, concerns and attitudes towards teaching profession of faculty of education and pedagogical formation students. Bayburt Journal of Faculty of Education, 11(1), 253-269.

Demirtaş, H., Cömert, M., \& Özer, N. (2011). Pre-Service teachers' self-efficacy beliefs and attitudes towards profession. Education and Science, 36(159), 96-111.

Dereli, E., \& Acat, M. B. (2010). Motivation source and problems relative teacher occupation of preschool education teacher department students. The Journal of Institute of Social Sciences, 24, 173-187.

Dereli, İ. E. (2014). Examining preschool teacher candidates' liking child and motivations for teaching professions. Journal of Theoretical Educational Science, 7(4), 482-504. https://doi.org/10.5578/keg.6950

Donmuş, V., Akpunar, B., \& Eroğlu, M. (2017). The investigation of the relationship between the academic self-efficacy and occupational anxiety of teacher candidates. Mustafa Kemal University Journal of Social Sciences Institute, 14(37), 1-13.

Downing, J. E., Ryndak, D. L., \& Clark, D. (2000). Paraeducators in inclusive classrooms: their own perceptions. Remedial and Special Education, 21, 171-181. https://doi.org/10.1177/074193250002100308

Durdukoca, Ş. F. (2010). Analysis of academic self-efficiency beliefs of elementary school teacher candidates using different variables. Bolu Abant İzet Baysal University Journal of Faculty of Education, 10(1), 69-77.

Durualp, E., \& Kaytez, N. (2016). Evaluation of Pre-School Teachers' Job Satisfaction From the Point of Their Children Love and Other Variables. Pegem Journal of Education and Instruction, 6(1), 97-112. https://doi.org/10.14527/pegegog.2016.006

Durualp, E., \& Ünal, N. (2013) The Research of Preschool Teachers' Liking Children Levels In terms of Sociodemographic Variables. 5. International Education Research Congress, 6-9 June, Çanakkale.

Duyan, V., \& Gelbal, S. (2008). The adaptation study of Barnett liking of children scale to Turkish. Education and Science, 33(148), 40-48.

Ekici, G. (2008). The effects of the classroom management lesson on preservice teachers' teacher sense of self-efficacy. H. U. Journal of Education, 35, 98-110. 
Erdem, Y., \& Duyan, V. (2011). A determination of the factors that affect the level of pediatric nurses' liking of children. Turkish Journal of Medical Sciences, 41(2), 295-305.

Faiz, M., Körükcü, M., \& Karadeniz, O. (2016). The analysis of the relation between social studies and primary school teachers ' levels of liking of children and their job satisfaction in terms of diverse variable. Journal of Human Sciences, 13(3), 4861-4875. https://doi.org/10.14687/jhs.v13i3.4204

Fritz, J. J., Miller-Heyl, J., Kreutzer, J. C., \& MacPhee, D. (1995). Fostering personel teaching efficacy through staff development and classroom activities. Journal of Educational Research, 88(4), 200-209. https://doi.org/10.1080/00220671.1995.9941301

Gelbal, S., \& Duyan, V. (2010). Examination of variables affecting primary school teachers' state of liking of children. H. U. Journal of Education, 38, 127-137.

Gencer, A. S., \& Cakıroglu, J. (2007). Turkish preservice science teachers' efficacy beliefs regarding science teaching and their beliefs about classroom management. Teaching and Teacher Education, 23(5), 664-675. https://doi.org/10.1016/j.tate.2005.09.013

Gercek, C., Yılmaz, M., Koseoğlu, P., \& Soran, H. (2006). Biology education teacher candidates' self efficacy beliefs in biology education. Ankara University Journal of Faculty of Educational Sciences, 39(1), 57-73.

Güney, S. (2011). Organizational Behavior. Ankara: Nobel Press

Gürbüztürk, O., \& Şad, S. N. (2009). Student teachers' beliefs about teaching and their sense of self-efficacy: A descriptive and comparative analysis. İönü University Journal of Faculty of Educatıon, 10(3), 201-226.

Güven, M., \& Gökdağ, B. M. (2017). Self-Efficacy, Learning Strategies and Learning Styles of Teacher Candidates: Anadolu University Example. Anadolu Journal of Educational Sciences International, 7(2), 288-337. https://doi.org/10.18039/ajesi.333735

Holzberger, D., Philipp, A., \& Kunter, M. (2013). How teachers' self-efficacy is related to instructional quality: A longitudinal analysis. Journal of Educational Psychology, 105(3), 774. https://doi.org/10.1037/a0032198

Hoy, W. K., \& Miskel, C. G. (2010). Education Management (Translate. Edt: S. Turan). Ankara: Nobel Press

Ilgaz, G. (2011). Investigation of elementary learners' perceptions on self-regulated learning strategies, self-efficacy and learner autonomy in science and technology course. Unpublished PhD thesis. Gazi Üniversity, Ankara, Turkey.

Kabaklı, Ç. L. (2015). "The examınatıon of varıables affectıng educatıon faculty of student's state of likıng of chıldren. Electronic Turkish Studies, 10(11), 811-830.

Kabaran, H., Altıntaş, S., \& Kabaran, G. G. (2016). Investıgation of the relationship between prospective teachers' educational internet use self-efficacy beliefs and academic self-efficacy beliefs. Journal of Educational Theory and Practical Research, 2(1), 1-11.

Karahan, Ş., \& Balat, G. U. (2011). The analysis of self-efficacy perception and burnout level of special education school educators. Pamukkale University Journal of Faculty of Education, 29(29), 1-14.

Kauffman, D. F., Yılmaz, S. M., \& Duke, B. (2011). Validation of the motivation to teach scale. H. U. Journal of Education, 40, 279-290.

Kaynak, B. K., Ergin, B., Arslan, E., \& Pinarcık, Ö. (2015). The examination of the relationship between the self-esteem of pre-school teacher candidates and their liking of children. Elementary Education Online, 14(1), 8696. DOI: $10.17051 /$ io.2015.35947

Klassen, R. M., \& Tze, V. M. (2014). Teachers' self-efficacy, personality, and teaching effectiveness: A meta-analysis. Educational Research Review, 12, 59-76. https://doi.org/10.1016/j.edurev.2014.06.001

Korkut, K., \& Babaoğlan, E. (2012). Prımary school teachers' self efficacy. Internatıonal Journal of Management Economics and Business, 8(16), 269-281.

Kozcu, Ç. N., \& Senler, B. (2007). Determination of self-efficacy beliefs of science and primary school pre-service teachers (Muğla Universtiy Sample). 16th National Congress of Educational Sciences. Gaziosmanpaşa University Faculty of Education, 5-7 September 2007.

Kuşcu, Ö., Erbay, F., Acar, Ş., \& Gülnar, E. (2015). Analysis of preschool teacher candidates attitudes towards the teaching profession children liking status. INES Journal, 2(3), 114-122.

Malmberg, L. E. (2006).Goal-orientation and teacher motivation among teacher applicants and student teachers. Teaching and Teacher Education, 22, 58-76. https://doi.org/10.1016/j.tate.2005.07.005 
McGeown, S. P., Putwain, D., Geijer, Simpson, E., Boffey, E., Markham, J., \& Vince, A. (2014). Predictors of adolescents' academic motivation: Personality, self-efficacy and adolescents' characteristics. Learning and Individual Differences, 32, 278-286. https://doi.org/10.1016/j.lindif.2014.03.022

Morgil, İ., Seçken, N., \& Yücel, A. S. (2004). Based on some investigation of self-efficacy beliefs of preservice chemistry teachers variables. Journal of Ballkesir University Institute of Science and Technology, 6(1), 62-72.

Nakip, C., \& Özcan, G. (2016). The relation between preservice teachers' sense of self efficacy and attitudes toward teaching profession. Mersin University Journal of Faculty of Educatıon, 12(3), 783-795. https://doi.org/10.17860/mersinefd.282380

Özdemir, S. M. (2008). An investigation of prospective primary teachers' self-efficacy beliefs regarding teaching process in terms of certain variables. Educational Administration: Theory and Practice, 54, 277-306.

Özkara, Y. (2013). The profile of pre-service teachers'tendencies towards liking of children. International Journal of Academic Research, 5(3), 230-234. https://doi.org/10.7813/2075-4124.2013/5-3/B.35

Pajares, F (1996). Self-efficacy beliefs in academic settings, Review of Educational Research, 66(4), 543-578. https://doi.org/10.3102/00346543066004543

Pajares, F., \& Schunk, D. (2001). The Development of Academic Self-efficacy. In A. Wigfield \& J. Eccles (Eds.), Development of Achievement Motivation. San Diego, CA: Academic Press.

Recto, A. S. (2005). Foundations of education. Anthropological, psychological, sociological, \& moral. Manila: Rex Book Store.

Saltalı, N. D., \& Erbay, F. (2013). Examination of speaking, listening, empathy skills of preschool teachers in terms of liking of children. Ahi Evran University Kırşehir Faculty of Education Journal (KEFAD), 14(1), 159-174.

Schiefele, U., \& Schaffner, E. (2015). Teacher interests, mastery goals, and self-efficacy as predictors of instructional practices and student motivation. Contemporary Educational Psychology, 42, 159-171. https://doi.org/10.1016/j.cedpsych.2015.06.005

Schunk, D. H. (1985). Participation on goal setting: Effects on self-efficacy and skills of learning disabled children. Journal of Special Education, 19, 307-317. https://doi.org/10.1177/002246698501900307

Skaalvik, E. M., \& Skaalvik, S. (2010). Teacher self-effi cacy and teacher burn put: A study of relations. Teaching and Teacher Education, 26, 1059-1069. https://doi.org/10.1016/j.tate.2009.11.001

Skaalvik, E. M., \& Skaalvik, S. (2017). Teacher Stress and Teacher Self-Efficacy: Relations and Consequences. In Educator Stress (pp. 101-125). NY: Springer. https://doi.org/10.1007/978-3-319-53053-6_5

Tabachnick, B. G., \& Fidell, L. S. (2013). Using Multivariate Statistics, Boston: Pearson/Allyn \& Bacon.

Tabancal1, E., \& Çelik, K. (2013). The relationship between academic self-efficacy and self-efficacy levels of teacher candidates. Journal of Human Sciences, 10(1), 1167-1184.

Tschannen-Moran, M., \& Woolfolk-Hoy, A. (2001). Teacher efficacy: Capturing an elusive construct. Teaching and Teacher Education, 17, 783-805. https://doi.org/10.1016/S0742-051X(01)00036-1

Uğurlu, C. T. (2013). Communicatıon skills of teachers and the effect of emphatic tendency behavior on levels of liking of children. Pegem Journal of Education and Instruction, 3(2), 51-61. https://doi.org/10.14527/V3N2M5

Üzel, C. D., \& Evin, G. İ. (2015). Adaptation of the motıvatıon to teach scale into Turkısh. Mehmet Akif Ersoy University Faculty of Education Journal, 1(36), 72-89.

Wang, H., Hall, N. C., \& Rahimi, S. (2015). Self-efficacy and causal attributions in teachers: Effects on burnout, job satisfaction, illness, and quitting intentions. Teaching and Teacher Education, 47, 120-130. https://doi.org/10.1016/j.tate.2014.12.005

Watt, H. M. G., \& Richardson, P. W. (2007). Motivational factors influencing teaching as a career choice: development and validation of the FIT-Choice Scale. Journal of Experimental Education, 75(3), 167-202. https://doi.org/10.3200/JEXE.75.3.167-202

Woolfolk, A. E., \& Hoy, W. K. (1990). Prospective teachers' sense of efficacy and beliefs about control. Journal of Educational Psychology, 82, 81-91. https://doi.org/10.1037/0022-0663.82.1.81

Woolfolk, A. E., Rosoff, B., \& Hoy, W. K. (1990). Teacher's sense of efficacy and their beliefs about managing students. Teaching and Teacher Education, 6, 137-148. https://doi.org/10.1016/0742-051X(90)90031-Y

Yazıc1, H. (2009). Teaching profession, motivational resources and basic attitudes: A theoretical perspective. Kastamonu 
Education Journal, 17(1), 33-46.

Yazıc1, Z. (2013). The examination of pre-service preschool teachers' towards liking children. Mediterranean Journal of Humanities, 3(2), 279-286. https://doi.org/10.13114/MJH/201322484

Yenice, N. (2012). İnvestigating the self-efficacy and problem solving skills of preservice teachers. Electronic Journal of Social Sciences, 11(39), 36-58.

Yıldırım, A., \& Şimşek, H. (2011). Qualitative research methods in the social sciences. Ankara: Seçkin Press.

\section{Copyrights}

Copyright for this article is retained by the author(s), with first publication rights granted to the journal.

This is an open-access article distributed under the terms and conditions of the Creative Commons Attribution license which permits unrestricted use, distribution, and reproduction in any medium, provided the original work is properly cited. 